\title{
Ágnes Csiszárik-Kocsir
}

\section{Crisis and Financing - or the Practical Financing Decisions of Hungarian Small and Medium-sized Enterprises ${ }^{1}$}

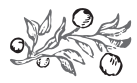

\section{Summary}

The standard operational mechanism of economies was substantially overwritten by the economic crisis of 2008. Due to the relative abundance of resources and the lenient banking practices prior to the crisis that focused on bonuses, there were no barriers to lending, which was possible both in foreign or in the national currency. The financial problems that followed the outbreak of the crisis ended the previous lending practice, and the abundance of resources was replaced by poor liquidity, which - along with the macro-economic predicaments - further complicated the struggle by companies to keep their heads above water. The indebtedness of the private sector, increasing input costs, the tightening of the markets and the decline in consumption caused such difficulties in financing enterprises both at a national and international level that after several years a solution had still not been found for them. The negative effects hit the most those small and medium-sized enterprises that had only limited or no access to the international capital markets. The aim of this present paper is to show the transformation of Hungarian small and medium-sized enterprise financing based on the academic literature and the results of questionnaire-based research, and to highlight the main problems and the reactions to them that point the way to recovery. A further goal of the paper is to present the future path for financing the sector and the factors that will influence this path through an improvement in the tax system or support for credit.

Journal of Economic Literature (JEL) code: G01, G30, E51

Keywords: crisis, financing, financing theories, internal financing, external financing

Dr ÁGnes Csiszárik-Kocsir PhD, Associate Professor, Óbuda University, Keleti Faculty of Business and Management (kocsir.agnes@kgk.uni-obuda.hu). 
Ágnes Csiszárik-Kocsir: Crisis and Financing - or the Practical Financing Decisions...

\section{LITERATURE OVERVIEW}

\section{Dominant theories of capital structure now and then}

When we talk about the financing of enterprises and businesses then resources always need to be examined from two aspects. If the structure of financing is examined by the origin of resources, then there are internal resources that derive from the operation of the enterprise, and there are external ones that come from the financial markets. Another interpretation is that resources can be differentiation by their time span, or in other words there are short term (of no more than a year) and long term (of more than a year) resources. Experts in corporate financing have long been interested in the optimal combination of the sources of financing. However, if we think about it, an optimal combination applicable to all businesses cannot exist in any given circumstance, because every company moves in a different market, works with different partners and has potential access to different capital items. In addition to the above, capital structure is also affected by the size and the age of the business, since older and larger enterprises are able to call on external resources more easily, more efficiently and with a smaller cost of capital than their younger and smaller rivals. In the case of older and larger enterprises professional knowledge and the system of relationships are dominant, as a result of which newer and more effective channels are opened up to them in the field of financing (Cabra-Mata, 2003). The choice between internal and external resources also depends on which stage of its life curve the enterprise is in (Ang, 1991). Companies in an early stage do not possess enough internal resources and their financial history is also short so they are not considered to be creditworthy, contrary to companies at the top of their life curve which have sufficient internal resources due to the retaining of their profits, and their history is well-known (Diamond, 1989) to external providers who are keen to lend funds to them.

Financial specialists have been concerned about the theories of capital structure since the middle of the last century. They were trying to find an explanation of the financing decisions of enterprises that could be true in general.

The oldest of the theories is the classic capital market theorem of Modigliani and Miller (Brealey-Meyers, 1999), which is also known as the irrelevance principle (Modigliani-Miller, 1958). According to this theory the financing structure has basically no impact on the corporate value, which is calculated using significant assumptions (there are no taxes or transaction costs), so the value of the company - in essence - is subject to the assets on the balance sheet. The theorem received numerous criticisms for its simplifications, and that is why a number of new theories attempted to resolve and modify it.

The trade-off theory has been interpreted by several authors. Compared to the classic theorem, it also calculates the value of the interest tax shield, which might make debt financing more favourable than equity financing. The original trade-off theory had also been created by Modigliani and Miller (1963), and then later it was further improved by other eminent authors. The theory states that it would be worthwhile to 
be in debt, although the financial difficulties caused by indebtedness and the high cost of bankruptcy should not be forgotten (Kim, 1978).

The principal - agent theory has been discussed before in connection with many financing issues. The father of the theory is Williamson (1998), who stated that the principal - the owner of the enterprise - does not have an adequate amount of information when making decisions about financing because certain tasks are delegated to the agent or, in other words, to the manager. Managers provide significant help in the operation of business, but the information in their possession may lead to an abuse of knowledge. Hence, due to the information asymmetry, it must also be taken into account that the manager might not choose the financing option most favourable to the company.

The pecking order theory (Myers-Majluf, 1984) is related to the previous approach. Information asymmetry is the reason why investors do not possess accurate data on a company's assets, therefore if the company wants to invest, first it will have to resort to internal resources, primarily for reinvested earnings. In cases where they are not sufficient or not available, then the company will need to access external resources. Of the external resources it is mainly the least risky forms that are preferred, such as bond and debt financing, which contain a repayment obligation but do not provide voting rights. Convertible bonds are next in line, followed by a capital increase from an external source.

The transaction cost theory (Coase, 1934) states that financing by external capital is cheaper, since it has a lower transaction cost. This is explained by the fact that, in this case, the information is ready to hand. When financing with their own capital, potential investors have significant informational needs, the cost of which is quite high. Investors require all the information regarding the subject of the investment or the securities issued.

Finally, the classic description of financing theory (Grochla, 1976) is worth mentioning as well. The theory tries to establish the optimal financing structure by characterizing it according to four aspects: forms of financing, exceptional events, analysis and planning; based on this, the approach shows the advantages and disadvantages of the individual forms.

However, the economic crisis that hit its peak in 2008 significantly rewrote the operational mechanism of economies and, in fact, in many cases it even questioned the legitimacy of the financing theories. Krugmann (2009) noted that these theories had been created by economists thinking in models. The theories often encouraged banks to bring risky credit products to the market that were popular but also very dangerous. Besides this, they prompted financial institutions to promote an extremely strong lobbying strategy for their products towards the financial market authorities. Another consequence of the crisis was the appearance of new theories that can undoubtedly be extrapolated to corporate financing as well. These theories focus on three alternatives (Scherer-Marti, 2012):

- positivistic finance conception that helps in predicting and controlling the movements of financial markets, but also has numerous limitations, 
Ágnes Csiszárik-Kocsir: Crisis and Financing - or the Practical Financing Decisions...

- postmodern perspectives on finance that concentrates instead on the financial market actors, and puts the emphasis on better communication and understand between them,

- constructive perspectives on finance that focuses on common language and understanding each other.

\section{The impact of the crisis on lending and the answers to the problem from the SME side}

Money and lending are essential elements of modern economies. The formula for macro-economic income also puts the banks and their reallocation of funds in a central role. Nevertheless, it should not be forgotten that this reallocation of funds also ends up at companies in the form of investments - that is to say that banks, on the basis of classical economic doctrines, provide the collected savings as loans to businesses that use them for investment purposes.

It is of the utmost importance for companies and businesses to receive sufficient operating funds. The rapidly changing environment and the competitive situation do not allow the companies to delay their investment needs until they possess sufficient resources of their own to carry them out. This is why the role of lending is crucial. Borrowed funds are especially important for smaller companies (SMEs), since their capital-market relationships are not as developed as those of larger companies, who can acquire the necessary resources directly from the financial markets. Moreover, in a crisis situation the financial intermediaries also tend to be oriented towards the larger companies because they can be monitored more easily and have more stable positions, and therefore the credit provided represents a lower risk than lending to the SME segment. Therefore, the accessibility of resources is an indispensable condition for the growth of companies and, of course, the supporting macro-economic background is just as important (Beck et al., 2001). The significance of lending and the effects of the decrease of lending are show in the figure below:

Small and medium-sized enterprises play an important role not only in Hungary but at an international level as well. Although their productivity is below that of larger companies, they are nevertheless the backbone of the economy. Two-third of employees are concentrated in their hands and, if we examine the number of these enterprises, we can see that they make up 99 per cent of the Hungarian total. ${ }^{2}$ This sector produces more than 40 per cent of the turnover ${ }^{3}$ and gross value added of all Hungarian companies. ${ }^{4}$ The number of SMEs has been continuously growing according to statistical data for the past three years, which confirms the ever-increasing role of the sector. The competitiveness and economic situation of this sector fundamentally determines the economic development and prosperity of a country (Varga, 2014).

In view of the above, it is extremely important for the existence and growth of the SME sector to be secured in Hungary both in the short and in the long term. To keep these businesses afloat, seamless operational financing is not enough; attention must be paid to investments too. As we know from macro-economics, the previously mentioned income equation shows that for the economy to expand we need investments 
Figure 1: The effects of the decrease of lending for the macro-economy as a whole

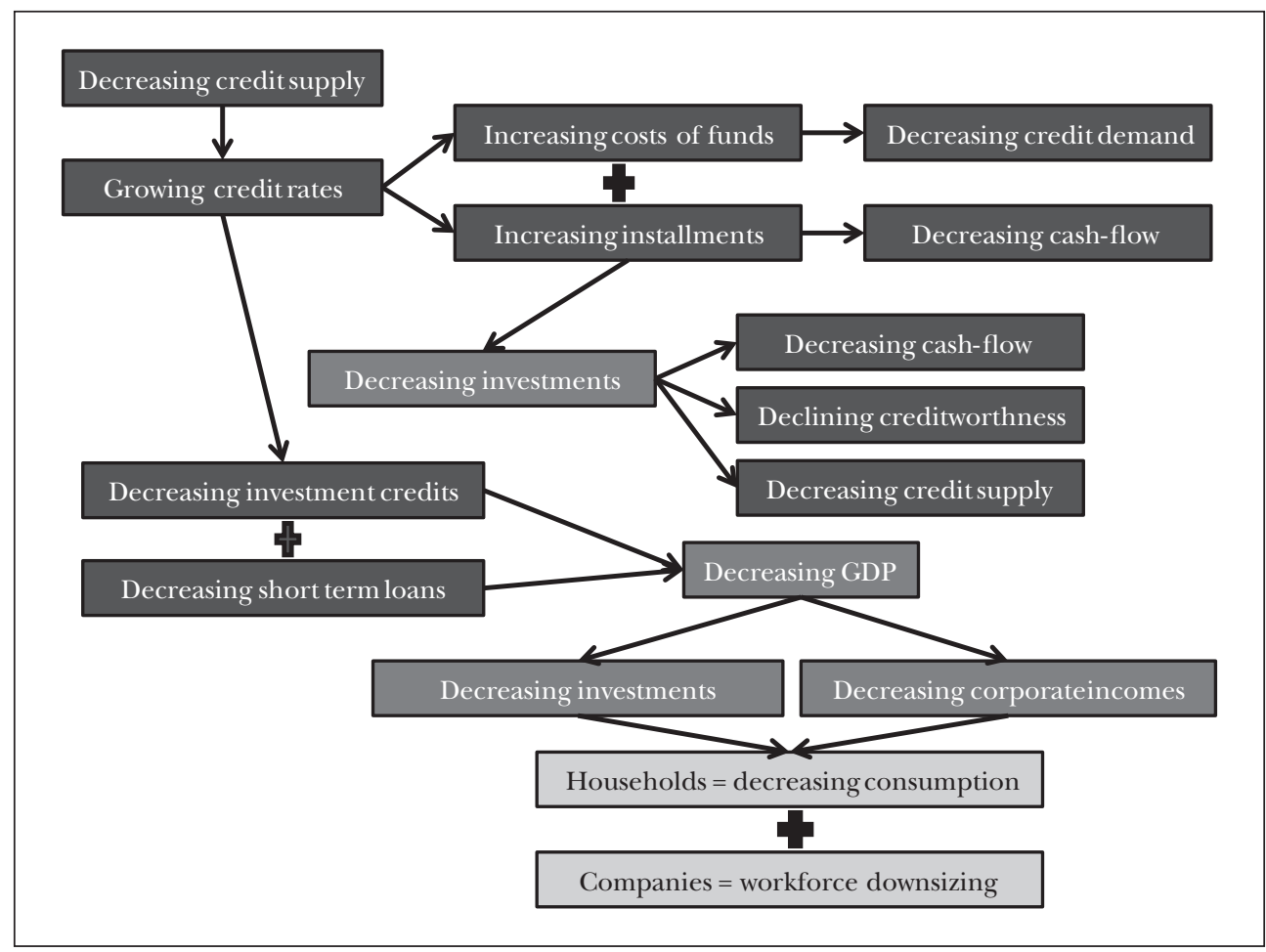

Source: The author based on Bauer-Oláh, 2016

Figure 2: The evolution of the number of small and medium-sized enterprises in Hungary between 2013 and 2015

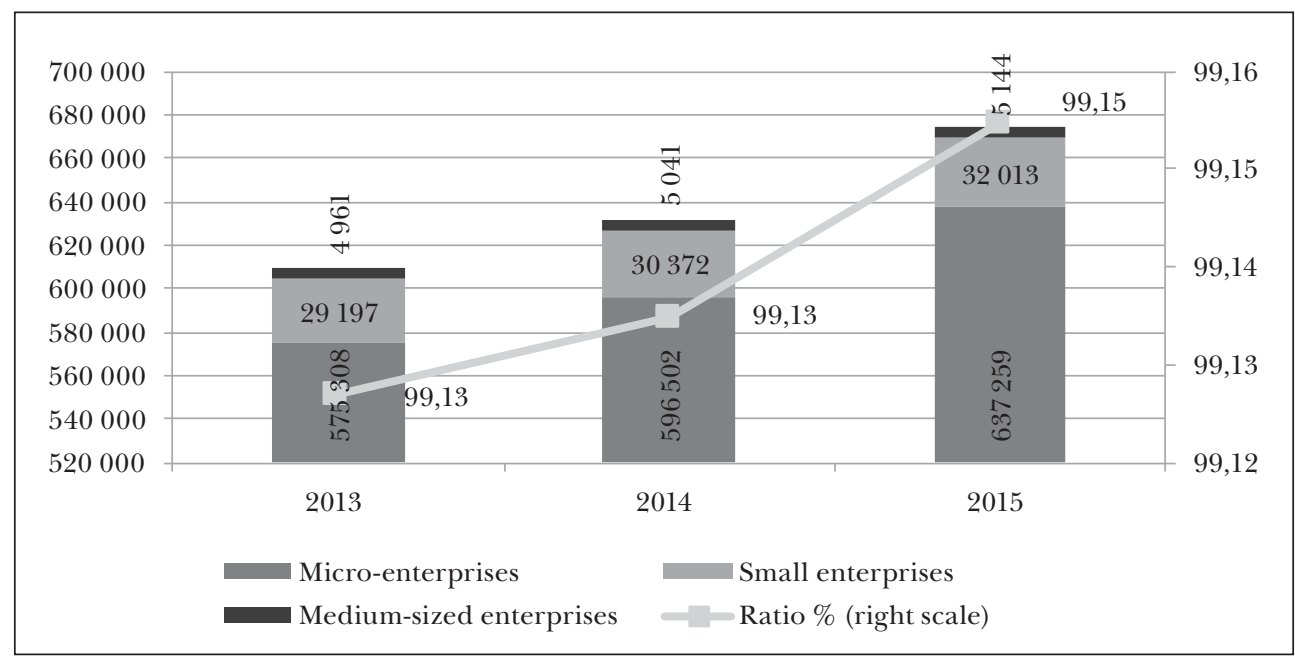

Source: Based on KSH 
on top of consumption, government purchases and income deriving from external relations. Unfortunately, in all respects we had lived beyond our means prior to the crisis. We consumed and bought on credit and made investments funded by loans, and for that reason there remains no way out of the crisis other than the rationalization of income from external sources (Lentner-Kolozsi-Tóth, 2010; Borzán-Lentner-Szigeti, 2011). However, the maximisation of export revenues and constraining of imports cannot be a satisfactory solution in the long term because the SME sector is only marginally involved due to the large-scale concentration of export relationships. That is why it is crucial for this sector to be able to invest and to receive the necessary funds to make investments; it is not able to do this on its own or only to a limited extent. Nearly 35 per cent ${ }^{5}$ of all the investments carried out by Hungarian companies can be attributed to the SME sector, and is mostly manifested in machines, equipment and construction projects. On the other hand, we have to bear in mind that the vast majority of Hungarian SMEs operate in the tertiary sector, which has an influence on their investment activity too. The most typical investment areas of the sector are agriculture, industry and trade.

\section{Figure 3: Performance indicators of Hungarian enterprises (in HUF billions)}

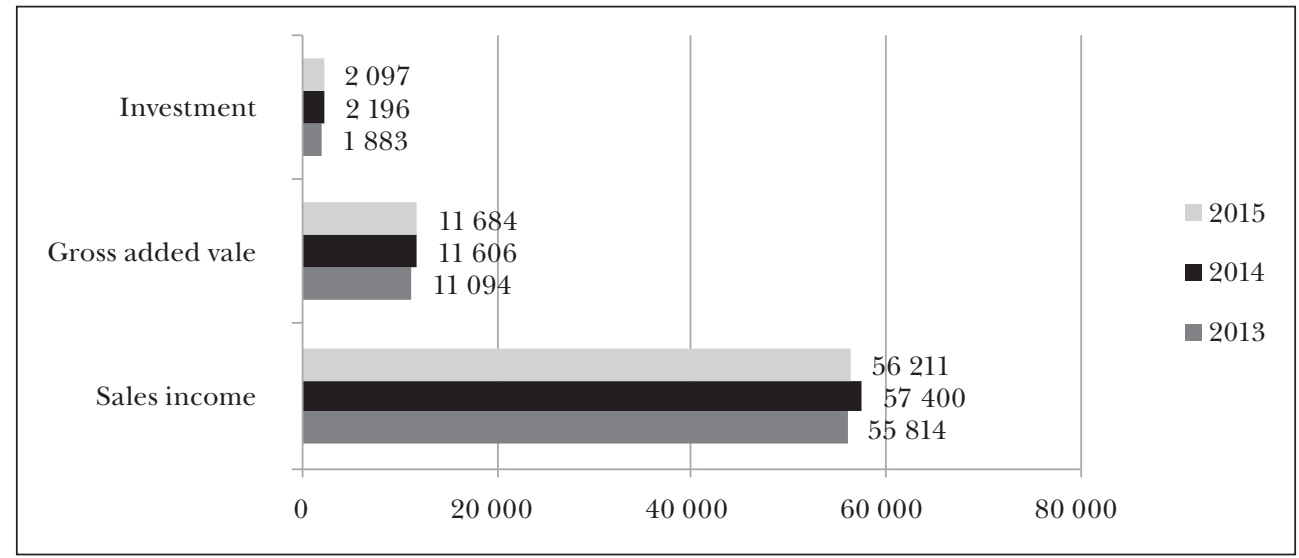

Source: Based on KSH

Accessible external resources have a decisive impact on SME investments. Due to the investments by this sector, the structure and balance of the companies' fixed assets is improving, which increases their efficiency of production. The improving efficiency and better quality of the output also enhance competitiveness, which contributes substantially to the development of the economy. The sector is often criticised for carrying out little investment, and consequently being unable to significantly assist economic growth. Some of the criticism is true, as SMEs do only account for 35 per cent of investment, and so they need to be helped in this. Such an improvement has been attempted by the National Bank of Hungary through its Funding for Growth Scheme. 
In banking practice, corporate lending is the segment able to react most quickly to the economic circumstances caused by the crisis. Crises are unavoidable corollaries of modern economies, and so we are obliged to adapt to and prepare for them. Several articles and studies have already dealt with the causes of the crisis in 2008. Some look for those responsible on the demand side (households, companies, and countries), while others blame the supply side (banks and financial institutions), and some opinions accuse the regulators (supervisory authorities and central banks) of escalating the problems (Lentner-Szigeti-Borzán, 2011). The problems of the financial intermediary system first appear in the erosion of resources and in a declining willingness to take risks. Due to decreasing corporate revenues and shrinking markets caused by the crisis, the value of available cash flows is becoming reduced as well, causing difficulties with debt servicing, which will be an obstacle to the further taking of loans within a short period of time. It is, nevertheless, important to note that for the SME sector of European countries, this is the most available and usable external resource after the use of internal resources. Therefore the decline in lending at the same time preserves the financing difficulties of the SME sector, which is supported by the ECB survey.

Figure 4: Financing structure of euro area SMEs on the basis of the frequency of using the funding sources applied

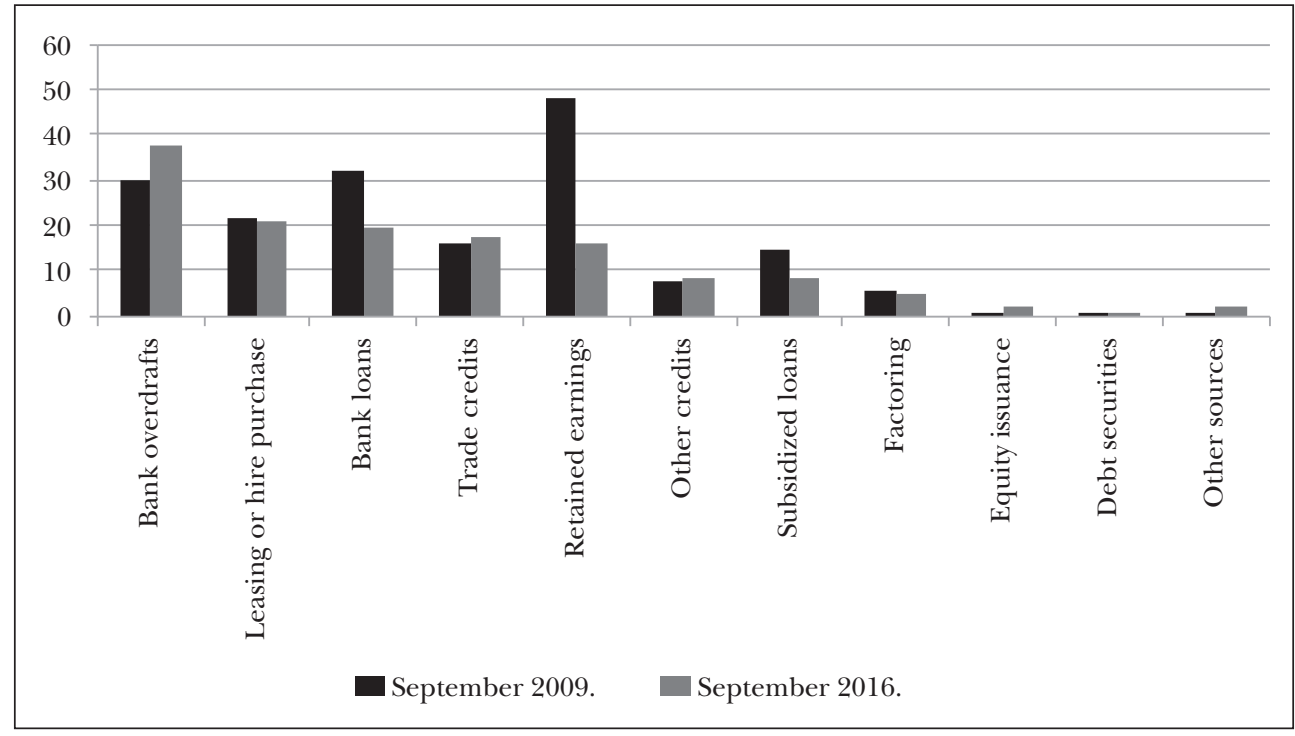

Source: The author based on ECB 2009; 2016

Lending to Hungarian SMEs had been expansive during the years prior the crisis due to the above-mentioned circumstances (Balog-Nagy, 2014), and was completely interrupted when the crisis spread into the country. Because of the drying-up of bank funds, the sector had no choice but to drain its savings and cut down its capacity in 
order to stay alive. Due to this survival reaction related to the crisis, necessary investments were not implemented, and for this reason the sector fell further behind its larger competitors. On account of the banks' careful conduct after the crisis, there has been an unprecedented downturn - at an international level too - in the loan stock of the corporate sector (Bauer-Oláh, 2016). As numerous studies have pointed out, the process of lending money to Hungarian companies began very late following the crisis, which can mainly be explained by decisions on the credit supply side (Sóvágó, 2011). As the above-cited study confirms, in our region the drop in lending was largest in Hungary, although the surge of lending had not been spectacularly high before the crisis. Neither did the decline in lending did not stop in 2013 (Fábián, 2014). To that effect, the National Bank of Hungary launched an interest rate subsidy programme in 2012 that did improve the conditions of companies in terms of lending, but it failed to bring decisive results, as market-based lending recovered only very slowly or not at all (Bauer, 2016). Lending to non-financial companies (including SMEs) is illustrated in the figure below, which clearly shows the setback in stock data during the post-crisis years.

Figure 5: Holdings of non-financial companies' obligations - and more specifically of their debt securities - between 2000 and 2015 in Hungary

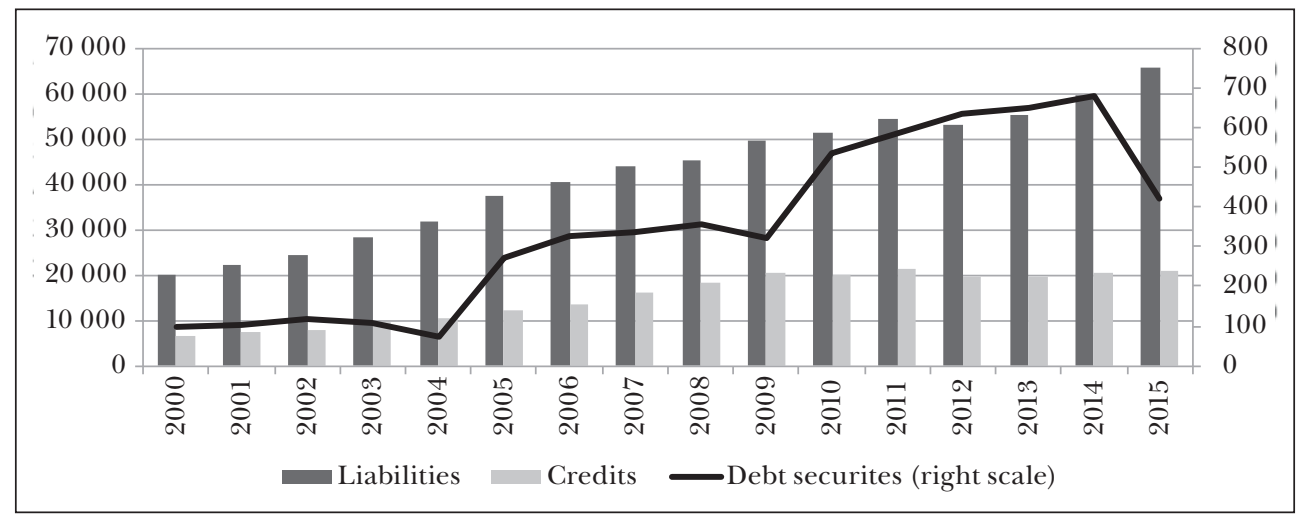

Source: The author based on MNB, 2016

The effect of the crisis is best demonstrated by the value of transactions made within the same period of time. We can see from this that companies tried to eliminate debts instead of substantially increasing their stock of loans after the end of the crisis, with this being due to demand and, above all, supply factors. It also becomes clear from the graph that the lending crisis that followed on from the economic crisis could only be fully solved in 2013.

The low level of lending activity, plunge in the investment ratio and protracted impact of the crisis triggered the Funding for Growth Scheme (FGS) in Hungary, as has been previously mentioned. The explicit objective of the programme is to provide funds for the SME sector that are able to reverse the dominant lending tendencies of 
Figure 6: Transactions of non-financial companies' liabilities - and more specifically of their debt securities - between 2000 and 2015 in Hungary

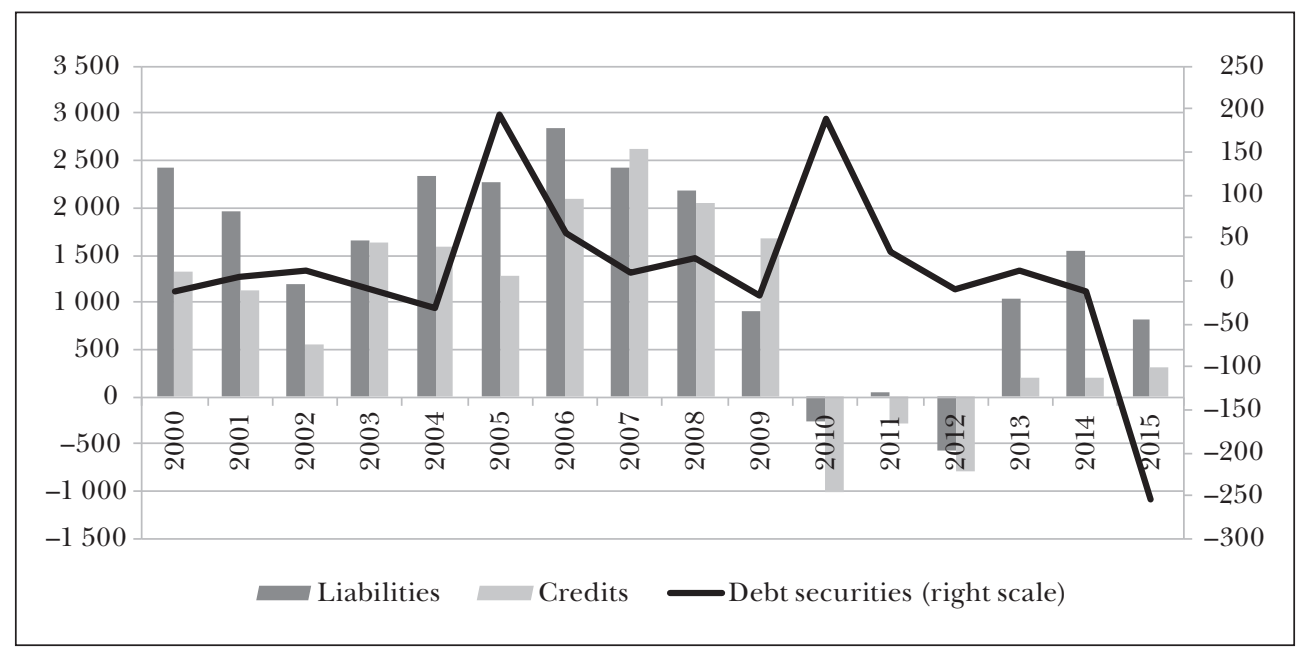

Source: The author based on MNB, 2016

the post-crisis era. Since market-based lending did not open its gates to this sector, or did so only slowly, there remained no means to change the situation other than the intervention of the Central Bank. The FGS has been subject to countless criticism ever since its launch. Some call it a "shaky air rifle" while others define it as a "machine gun" (Plajner-Pulai, 2016), but it is nevertheless inevitable that without it many small and medium-sized enterprises would not have been able to acquire enough resources for their operations and investments. ${ }^{6}$

\section{FinANCING ANOMALIES OF HUNGARIAN SMES BASED ON THE RESULTS OF A QUESTIONNAIRE SURVEY}

\section{Material and methodological background}

The basis of the study is primary research conducted in 2016 through a pre-tested and standardized questionnaire. ${ }^{7}$ The research is still ongoing and the results shown here are only partial ones, reflecting the opinion of 592 companies that have filled out the questionnaire form. The questionnaire assessed the opinions of the companies in three areas: financing, investment activity and project management. The present paper deals with the evaluation of the results on financing. The finalization of the questionnaire was preceded by in-depth interviews, and the questionnaire form was then created using the outcome of the qualitative research. The questionnaire contained only closed questions in the interests of a better assessment of the sample and the answers. There was an earlier round of research between 2013 and 2015, prior to the present form of the questionnaire, where the same thematic areas were assessed 
but with fewer questions. The sample consists mainly of SMEs because of their weight and economic dominance. The questionnaire was filled out anonymously by the companies, with their identity not being revealed in any way. Due to the segmentation of the sample, the research dealt only with the type of company, scope of activities, ratio of domestic ownership, and the main balance sheet and income data (net sales revenues, earnings after taxes, and balance sheet total). The results are not considered representative, but they allow for the possibility of establishing and conducting representative research at a later date. The above-mentioned sample was assessed using SPSS 19.0 and MS Excel 2010.

In the present study the sample was analysed by balance sheet and income data of the previous full financial year. The composition of the sample is shown in the table below:

Table 1: Composition of the sample by sales revenues, earnings after taxes and balance sheet total

\begin{tabular}{l|l|l|l|l|l|l}
\hline & \multicolumn{2}{l|}{ Sales income } & \multicolumn{2}{l|}{ Net income } & \multicolumn{2}{l}{ Total assets } \\
\hline & count & Sample \% & count & Sample \% & count & Sample \% \\
\hline 0-50 million HUF & 318 & 53.7 & 437 & 73.8 & 360 & 60.8 \\
\hline 51-100 million HUF & 61 & 10.3 & 65 & 11.0 & 72 & 12.2 \\
\hline $101-250$ million HUF & 73 & 12.3 & 26 & 4.4 & 44 & 7.4 \\
\hline 251-500 million HUF & 36 & 6.1 & 12 & 2.0 & 18 & 3.0 \\
\hline 501-1000 million HUF & 20 & 3.4 & 19 & 3.2 & 36 & 6.1 \\
\hline Above 1000 million HUF & 84 & 14.2 & 33 & 5.6 & 62 & 10.5 \\
\hline
\end{tabular}

Source: Research by the author, 2016, N= 592

Results

In the part of the research presented in this paper the preferred financing forms of Hungarian companies was assessed. They were first asked whether, from among the available sources of financing, they preferred internal ones from the owners or created by the operation of the enterprise, or external resources deriving from the financial and capital markets. 71.1 per cent of the 592 companies in the sample chose internal financing, whereas 28.9 per cent of them preferred external finance. However, during years of economic crisis when the revenues are becoming lower, and therefore usable and recyclable cash-flow is decreasing as well, companies do not much opportunity to reinvest significant resources into the company, because they need them to stay afloat and to finance daily operations. In line with this, the resources available for investment are so scarce that enterprises cannot use them to implement meaningful developments.

Next the resource preference of companies was examined by individual segment. The results are illustrated in the table below. Based on the results, it can be stated that more than 70 per cent of the smallest companies rely on internal resources (catego- 
ry \%). Interestingly, based on sales revenues, earnings after tax and the balance sheet total, medium-sized companies use external resources more often, with the average being around 40 per cent.

Table 2: Percentage of the usage of internal and external resources by groups by sales revenues, earnings after taxes and balance sheet total; and the tendency of Pearson's chi-square values

\begin{tabular}{|c|c|c|c|c|c|c|c|c|c|c|c|c|}
\hline & \multicolumn{4}{|c|}{ Sales income } & \multicolumn{4}{|c|}{ Net income } & \multicolumn{4}{|c|}{ Total assets } \\
\hline & \multicolumn{2}{|c|}{ Internal } & \multicolumn{2}{|c|}{ External } & \multicolumn{2}{|c|}{ Internal } & \multicolumn{2}{|c|}{ External } & \multicolumn{2}{|c|}{ Internal } & \multicolumn{2}{|c|}{ External } \\
\hline & 䒕 & 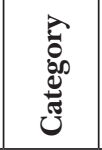 & है & 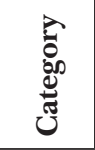 & $\begin{array}{c}\stackrel{0}{2} \\
\text { हूँ }\end{array}$ & 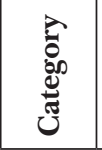 & $\begin{array}{l}\stackrel{0}{2} \\
\text { है }\end{array}$ & 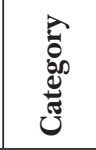 & 旁 & 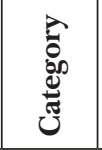 & $\begin{array}{l}\frac{0}{2} \\
\text { हुँ }\end{array}$ & 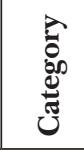 \\
\hline $0-50$ & $41.7 \%$ & $77.7 \%$ & $12.0 \%$ & $22.3 \%$ & $53.4 \%$ & $72.3 \%$ & $20.4 \%$ & $27.7 \%$ & $46.8 \%$ & $76.9 \%$ & $14.0 \%$ & $23.1 \%$ \\
\hline $51-100$ & $6.4 \%$ & $62.3 \%$ & $3.9 \%$ & $37.7 \%$ & $7.6 \%$ & $69.2 \%$ & $3.4 \%$ & $30.8 \%$ & $7.8 \%$ & $63.9 \%$ & $4.4 \%$ & $36.1 \%$ \\
\hline $101-250$ & $6.9 \%$ & $56.2 \%$ & $5.4 \%$ & $43.8 \%$ & $2.4 \%$ & $53.8 \%$ & $2.0 \%$ & $46.2 \%$ & $3.5 \%$ & $47.7 \%$ & $3.9 \%$ & $52.3 \%$ \\
\hline $251-500$ & $3.7 \%$ & $61.1 \%$ & $2.4 \%$ & $38.9 \%$ & $1.5 \%$ & $75.0 \%$ & $0.5 \%$ & $25.0 \%$ & $2.5 \%$ & $83.3 \%$ & $0.5 \%$ & $16.7 \%$ \\
\hline $\begin{array}{l}501- \\
1000 \\
\end{array}$ & $2.4 \%$ & $70.0 \%$ & $1.0 \%$ & $30.0 \%$ & $2.5 \%$ & $78.9 \%$ & $0.7 \%$ & $21.1 \%$ & $3.9 \%$ & $63.9 \%$ & $2.2 \%$ & $36.1 \%$ \\
\hline $\begin{array}{l}1001 \\
\text { above }\end{array}$ & $10.0 \%$ & $70.2 \%$ & $4.2 \%$ & $29.8 \%$ & $3.7 \%$ & $66.7 \%$ & $1.9 \%$ & $33.3 \%$ & $6.6 \%$ & $62.9 \%$ & $3.9 \%$ & $37.1 \%$ \\
\hline $\begin{array}{l}\text { Pearson } \\
\text { Chi }\end{array}$ & \multicolumn{4}{|c|}{0.002} & \multicolumn{4}{|c|}{0.396} & \multicolumn{4}{|c|}{0.000} \\
\hline
\end{tabular}

Source: Research by the author, 2016, $N=592$

In order to determine if there is a correlation between preference for internal or external resources and classification by the main balance sheet and income data, Pearson's chi-square values were also analysed. Based on these, there is a correlation between the two factors if the chi-square value is lower than 0.05 . The data from the sample shows that the sales revenues and balance sheet total of the respondent companies substantially influence the resource preference, as confirmed by the values obtained.

Following in a similar vein, in the next block the respondents were asked to rank their preference for internal and external resources when making financial decisions on a scale of one to four. ${ }^{8}$ As the table below shows, Hungarian SMEs prioritize internal resources. They mostly use reinvestment of the after-tax profit, since in this way the operation of the business produces the necessary resources to later serve as a foundation for investments. The resources with the next highest average rating are linked to rationalization, i.e. companies use their reserves first and then they reduce their assets. But what is interesting $s$ that this confirmed the common belief about amortization. Instead of functioning as a real reserve for future development, amortization works only as an additional resource prior to decreasing the stock of working capital, which acknowledges that this form of financing exists as an operative resource in the day-to-day activity of companies. In other words, amortization 
is considered to be a factor that reduces profit, and which is not reserved for subsequent development but instead is reinvested into the company's operations. The answers clearly show that it is the opinion of companies that external resources are used only after fully exploiting internal ones. Among external resources bank loans are clearly at the top, which coincides with the results of the ECB surveys. Bank loans are followed by commercial loans, meaning that companies are keen on turning to financing through suppliers. Unfortunately, in many cases this also involves the phenomenon of circular debt. Securities financing transactions is the least popular form, which can be explained by the underdeveloped capital-market relationships of Hungarian enterprises.

Figure 7: Assessment of internal and external resources on a scale of 1 to 4 by their usage, by mean and standard-deviation

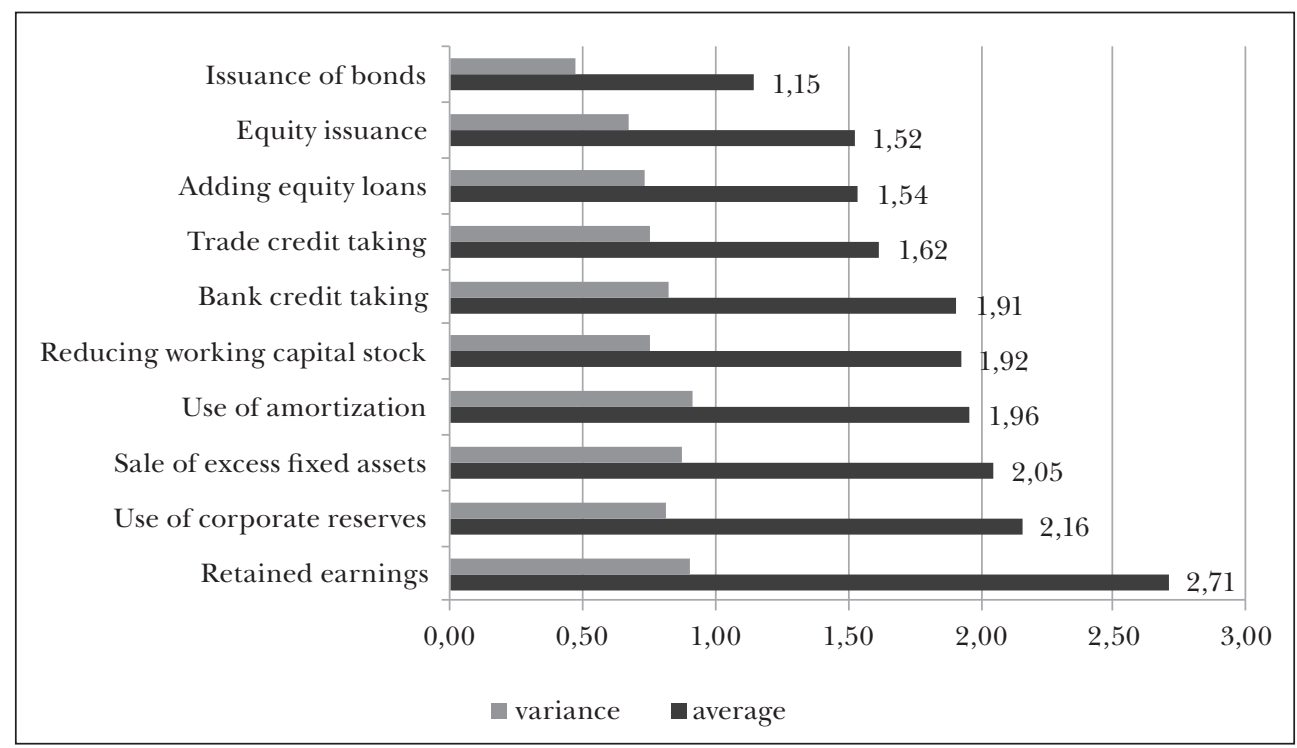

Source: Research by the author, 2016, $N=592$

The estimates of each type were further assessed by average rating, in order to judge whether the balance sheet and income data of companies have a decisive impact on the choice between internal and external resources. It can also be seen in the groups formed by sales revenues that the most favoured resource with the highest average rating was reinvestment of profits after tax, and in all cases the least favoured was the issuing of bonds. It is clear too that the companies with the lowest sales revenues place the use of commercial loans in second last place. The reason for this is that, due to their lower bargaining power, these companies are unable to exert significant influence on payment deadlines, or in other words the suppliers do not like giving them credit. By analysing the highest ratings it can be established that for the two groups with the highest sales revenues bank loans are the third most used source 
of funding. The largest enterprises are more likely take advantage of this opportunity more, since they are more creditworthy, and even when considering their income they are more stable with regard to the repayment of loans.

Table 3: Assessment of individual types of resources by groups formed on the basis of sales revenues by average ratings, and the tendency of Pearson's chi-square values

\begin{tabular}{|c|c|c|c|c|c|c|c|}
\hline & 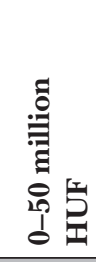 & 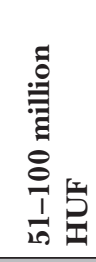 & 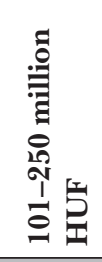 & 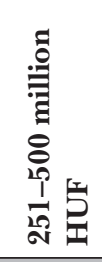 & 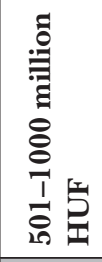 & 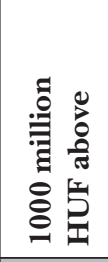 & 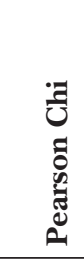 \\
\hline Retaining of earnings after tax & 2.63 & 2.69 & 2.77 & 2.72 & 2.90 & 2.92 & 0.014 \\
\hline Reducing working capital stock & 1.85 & 1.87 & 2.05 & 2.14 & 2.20 & 1.98 & 0.080 \\
\hline Sale of excess fixed assets & 1.97 & 1.97 & 2.19 & 2.33 & 2.30 & 2.10 & 0.003 \\
\hline Use of amortization & 1.80 & 2.15 & 2.18 & 1.94 & 2.00 & 2.24 & 0.003 \\
\hline Use of corporate reserves & 2.16 & 2.11 & 2.16 & 2.53 & 1.75 & 2.10 & 0.011 \\
\hline Bank credit & 1.73 & 2.02 & 2.12 & 2.22 & 2.20 & 2.13 & 0.000 \\
\hline Issuing bonds & 1.10 & 1.08 & 1.21 & 1.42 & 1.10 & 1.21 & 0.007 \\
\hline Equity loans & 1.55 & 1.49 & 1.68 & 1.56 & 1.40 & 1.45 & 0.709 \\
\hline Issuing equity & 1.47 & 1.51 & 1.70 & 1.42 & 1.40 & 1.67 & 0.034 \\
\hline Commercial credit & 1.45 & 1.80 & 1.88 & 1.83 & 1.55 & 1.85 & 0.000 \\
\hline
\end{tabular}

Source: Research by the author, 2016, $N=592$

Pearson's chi-square made it obvious again that there is a connection between the majority of the resource types (with the only exception being equity loans) and the groups formed by sales revenues, and so we can state that the choice of resources is undoubtedly affected by the size of a company's income.

Earnings after tax is the kind of income category that can be determined by fate, while their reinvestment or payment as a dividend is decided by the company. As these earnings are clear, meaning that creditors and taxes have been paid, they provide a much more accurate picture of the operation of companies than sales revenue. At the two end points of the assessment of resources are still earnings after tax and issuing bonds, but there is a high variance in preference for other types of resource. Companies with lower profits prefer rationalization (utilization of reserves and sales of surplus assets), but above the level of 50 million HUF bank loans come to the fore as one of the favoured sources of funding. Companies with earnings higher than 501 million HUF also opt for financing through bank loans, but the largest enterprises clearly turn to internal resources. Small and medium-sized enterprises are again the ones that deprioritize financing through suppliers. 
Ágnes Csiszárik-Kocsir: Crisis and Financing - or the Practical Financing Decisions...

Table 4: Assessment of individual types of resources by groups formed on the basis of earnings after taxes, by average rating, and the tendency of Pearson's chi-square values

\begin{tabular}{|c|c|c|c|c|c|c|c|}
\hline & 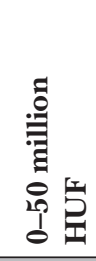 & 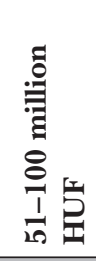 & 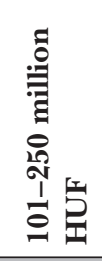 & 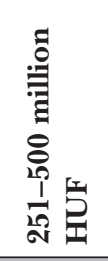 & 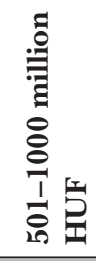 & 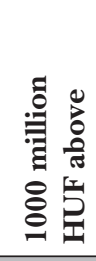 & 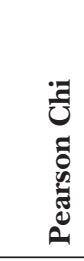 \\
\hline Retaining of earnings after tax & 2.67 & 2.69 & 2.65 & 2.83 & 2.95 & 3.12 & 0.090 \\
\hline Reducing working capital stock & 1.88 & 1.97 & 2.12 & 2.17 & 2.11 & 2.06 & 0.150 \\
\hline Sale of excess fixed assets & 2.01 & 2.05 & 2.23 & 2.25 & 2.05 & 2.33 & 0.004 \\
\hline Use of amortization & 1.89 & 2.00 & 2.19 & 2.42 & 2.42 & 2.21 & 0.008 \\
\hline Use of corporate reserves & 2.19 & 2.05 & 2.08 & 2.33 & 1.95 & 2.03 & 0.824 \\
\hline Bank credit & 1.81 & 2.20 & 2.19 & 2.00 & 2.32 & 2.21 & 0.000 \\
\hline Issuing bonds & 1.10 & 1.23 & 1.19 & 1.17 & 1.47 & 1.33 & 0.000 \\
\hline Equity loans & 1.56 & 1.54 & 1.42 & 1.67 & 1.42 & 1.39 & 0.692 \\
\hline Issuing equity & 1.47 & 1.58 & 1.50 & 1.67 & 1.74 & 1.88 & 0.016 \\
\hline Commerical credit & 1.54 & 1.77 & 2.00 & 1.50 & 1.95 & 2.00 & 0.001 \\
\hline
\end{tabular}

Source: Research by the author, 2016, N=592

According to the chi-square values, there are several types of resources for which there is no demonstrable correlation between the source of financing and the groups by earnings after tax (reduction of net working capital, utilization of corporate reserves, and equity loans). Therefore it is safe to say that the assessment and usage of external resources are more influenced by the amount of earnings after taxes than the assessment and usage of internal resources.

The most varied picture can be seen by balance sheet total. Once again, the companies with the largest assets are the ones that put bank loans as their resource of choice. Smaller companies instead rationalize, scale-back surplus assets and this is how they try to obtain funding. In general, the utilization of reserves is also a highly ranked type of resource. Hence it can be restated that companies with a large capital base are not afraid to borrow, and if needed they make use of this possibility. The least preferred resources clearly include equity loans, capital increases and the issuing of bonds.

The chi-square values again reveal a correlation in numerous cases. The balance sheet total shows no relationship with the types of resources in only two areas, namely the reduction of working capital and equity loans. Similarly to earnings after tax, it can also be established that the majority of the resources used depend on the balance sheet total of the company. 
Table 5: Assessment of individual types of resources by groups formed on the basis of balance sheet total, by average rating, and the tendency of Pearson's chi-square values

\begin{tabular}{|c|c|c|c|c|c|c|c|}
\hline & 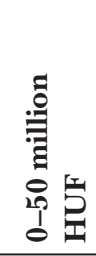 & 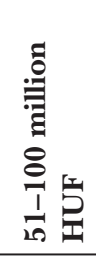 & 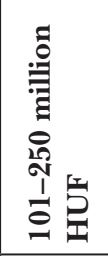 & 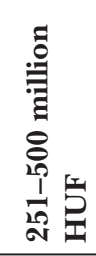 & 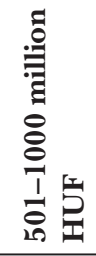 & 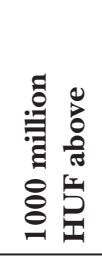 & 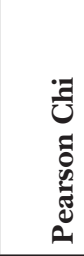 \\
\hline Retaining earnings & 2.65 & 2.63 & 2.91 & 2.83 & 2.78 & 2.94 & 0.014 \\
\hline Reducing working capital stock & 1.90 & 1.92 & 1.93 & 2.17 & 2.00 & 1.97 & 0.474 \\
\hline Sale of excess fixed assets & 2.04 & 1.85 & 2.23 & 2.50 & 1.89 & 2.19 & 0.000 \\
\hline Use of amortization & 1.86 & 2.03 & 2.14 & 2.11 & 1.94 & 2.34 & 0.037 \\
\hline Use of corporate reserves & 2.15 & 2.19 & 2.34 & 2.44 & 2.03 & 1.98 & 0.008 \\
\hline Bank credit & 1.76 & 2.13 & 2.05 & 2.17 & 2.17 & 2.21 & 0.000 \\
\hline Issuance of bonds & 1.11 & 1.13 & 1.16 & 1.44 & 1.25 & 1.23 & 0.001 \\
\hline Equity loans & 1.58 & 1.49 & 1.61 & 1.50 & 1.53 & 1.37 & 0.400 \\
\hline Issuing of equity & 1.48 & 1.53 & 1.59 & 1.50 & 1.39 & 1.77 & 0.038 \\
\hline Commerical credit & 1.48 & 1.83 & 1.86 & 1.89 & 1.75 & 1.89 & 0.000 \\
\hline
\end{tabular}

Source: Research by the author, 2016, N = 592

\section{ConcLusion}

The analysis above confirms that it has not been easy for Hungarian companies to emerge from the economic crisis. While companies in Europe and around the world already began to recover two to three years after the financial crisis with the help of available sources of financing, their Hungarian counterparts were still struggling with everyday operational problems. The banks did not move the recovery forward either, because several years after the end of the crisis market-based lending still had not started up, because at that time the banks were trying to solve the issues of forex loans and ease the difficulties caused by bank losses. So in the fifth year after the crisis there was no other choice remaining but to resolve the situation in a centralized way through the credit programme launched by the Central Bank. As the research results show, most companies need loans, regarding these as the most promising external sources of financing and that internal resources are insufficient. In terms of Hungarian companies, it can be established that following the financial crisis they endeavour to be cautious and rely primarily on internal resources, although there are companies with such small growth potential that they cannot collect enough internal funding for individual investments at all, or can do so only in the very long term, which is an approach that resembles the pecking order theory. In conclusion it can be stated 
that, for the sake of competitiveness and for the growth of the economy, external resources are indeed important for making necessary investments, especially loans, even if companies are reluctant to use them, because they must turn to these sources in order to maintain their market positions. Therefore, credit-based resources (even if in the form of aid) are necessary since they generate change both at the micro and the macro level, whether they function as an "air rifle" or as a "machine gun".

\section{Notes}

1 Supported through the New National Excellence Programme of the Ministry of Human Capacities.

$2 \quad 2013=99,13 \%, 2014=99,13 \%, 2015=99,15 \%$

$2013=43,2 \%, 2014=42,9 \%, 2015=42,4 \%$

$2013=44,3 \%, 2014=43,5 \%, 2015=43,0 \%$

$2013=35,5 \%, 2014=34,8 \%, 2015=34,1 \%$

6 The effects and benefits of the FGS are explained in detail by the publications of the Central Bank of Hungary: MNB 2014; 2016 and its thematic articles, in addition to what has been quoted above.

7 I would hereby like to thank the assistance of the students of Óbuda University, who contributed to the dissemination and filling out of the questionnaires.

8 Where 1 meant the least used resource and 4 represented the most often used type of resource.

\section{REFERENCES}

Ang, James S. (1991): Small Business Uniqueness and the Theory of Financial Management. Journal of Small Business Finance, vol. 1, no. 1, 1-3.

Bauer, Péter (2016): A Növekedési Hitelprogram 2013-2015. évi makrogazdasági hatásai [Macro-Economic Effects of the Funding For Growth Scheme Between 2013 and 2015]. In: Növekedési Hitelprogram. Magyar Nemzeti Bank, 46-59, www.mnb.hu/letoltes/novekedesi-hitelprogram-a-magyar-nemzeti-bank-hitelosztonzo-eszkozenek-tapasztalatai.pdf (accessed 10 December, 2016).

Bauer, Péter - Oláh, Zsolt (2016): Milyen veszélyeket rejt a hitelezési piac és a hitelközvetítés befagyása? [Threats In Freezing the Lending Market and Loan Intermediation]. In: Növekedési Hitelprogram. Magyar Nemzeti Bank, 9-20, www.mnb.hu/letoltes/novekedesi-hitelprogram-a-magyar-nemzeti-bank-hitelosztonzo-eszkozenek-tapasztalatai.pdf (accessed 20 October, 2016).

Balog, Ádám - Nagy, Márton (2014): Már nemcsak nálunk fontos a vállalati hitelek ösztönzése [Encouraging Corporate Lending Is Now Also Important In Other Countries]. Magyar Nemzeti Bank, www.mnb.hu/ letoltes/szakmai-cikk-balog-adam-nagy-marton-mar-nemcsak-nalunk-fontos-a-vallalati-hitelek-osztonzese.pdf (accessed 29 November, 2014).

Beck, Thomas et al. (2000): Financial Structure and Economic Development: Firm, Industry, and Country Evidence. Policy Research Working Paper 2423, The World Bank Development Research Group, Finance, Washington D.C., http://dx.doi.org/10.1596/1813-9450-2423.

Borzán, Anita - Lentner, Csaba - Szigeti, Cecília (2011): A pénzügyi vállalkozások felelôsségvállalásának új dimenziói [New Aspects of Financial Businesses' Responsiblity]. Economica (Szolnok), vol. 4, no. 11, 22-30.

Brealey, Richard A. - Meyers, Stewart C. (1999): Modern vállalati pénzügyek [Modern Financial Business]. Panem Kiadó, Budapest.

Cabral, Luis - Mata, José (2003): On The Evolution of the Firm Size Distribution: Facts and Theory. American Economic Review, vol. 93, no. 4, 1075-1090. doi: 10.1257/000282803769206205.

Coase, Ronald (1937): The Nature of the Firm. Economica, vol. 4, no. 16, 386-405.

Diamond, Douglas W. (1989): Reputation Acquisition in Debt Markets. Journal of Political Economy, vol. 97, no. 4, 828-862, https://doi.org/10.1086/261630. 


\section{Civic Review · Vol. 13, Special Issue, 2017}

ECB (2009): Survey on The Access to Finance of Small and Medium-Sized Enterprises in the Euro Area. European Central Bank, September 2009, www.ecb.europa.eu/pub/pdf/other/accesstofinancesmallmediumsizedenterprises200909en.pdf?46f55655c4142d1438b3d20b54f224cc (accessed 8 October, 2016).

ECB (2016): Survey On The Access To Finance of Enterprises in the Euro Area. European Central Bank, September, www.ecb.europa.eu/pub/pdf/other/accesstofinancesmallmediumsizedenterprises201611.en.pdf? 862f53698b8f84e198d67572453c4465 (accessed 22 November, 2016).

Fábián, Gergely (2014): Az NHP megforditotta a hitelszúke negatív spirálját [The FfG Has Turned the Negative Spiral of Shortage In Lending]. Magyar Nemzeti Bank, www.mnb.hu/letoltes/szakmai-cikk-fabian-gergely-nhp.pdf (accessed 29 November, 2014).

Grochla, Erwin (1976): Finanzierung, Begriff der. In: Handwörterbuch der Finanzwirtschaft. Poeschel, Stuttgart, 413-415.

Kim, E. Han (1978): A Mean-Variance Theory of Optimal Capital Structure and Corporate Debt Capacity. The Journal of Finance, vol. 33, no. 1, 45-63, 10.1111/j.1540-6261.1978.tb03388.x.

Krugman, Paul (2009): How Did Economics Get It So Wrong? The New York Times Magazine, 2 September.

Lentner, Csaba - Kolozsi, Pál - Tóth, Gergely (2010): A magyar válságkezelés sajátosságai és ellentmondásai [Peculiarities and Contradictions in Hungarian Crisis Management]. EU Working Papers, 2010/1, 3-17.

Lentner, Csaba - Szigeti, Cecília - Borzán, Anita (2011): New Dimension of Banks Social Responsibility. In: Abstracts of the 3rd International Conference of Economic Sciences: Sustainable Economics - Community Strategies. Eds. Szente Viktória et al., Kaposvári University, Kaposvár.

MNB (2014): Növekedési Hitelprogram. Az elsố 18 hónap [Funding For Growth Scheme. The First 18 Months]. Magyar Nemzeti Bank, www.mnb.hu/letoltes/novekedesihitelprogramazelso18honap.pdf (accessed 13 November, 2016).

MNB (2016): Növekedési Hitelprogram. A Magyar Nemzeti Bank hitelösztönzố eszközének tapasztalatai [Funding For Growth Scheme. Experiences of the National Bank of Hungary's Facility to Boost Lending]. Magyar Nemzeti Bank, www.mnb.hu/letoltes/novekedesi-hitelprogram-a-magyar-nemzeti-bank-hitelosztonzo-eszkozenek-tapasztalatai.pdf (accessed 10 December, 2016).

Myers, Stewart C. - Majluf, Nicholas S. (1984): Corporate Financing and Investment Decisions When Firms Have Information That Investors Do Not Have. Journal of Financial Economics, vol. 13, no. 2, 187-221, https://doi.org/10.3386/w1396.

Modigliani, Franco - Miller, Merton H. (1958): The Cost of Capital, Corporate Finance and the Theory of Investment. The American Economic Review, vol. 48, no. 3, 261-297.

Modigliani, Franco - Miller, Merton H. (1963): Corporate Income Taxes and the Cost of Capital: a Correction. The American Economic Review, vol. 53, no. 3, 433-443.

Plajner, Ádám - Pulai, György (2016): “Talán inkább sorozatlövố...”- 36 ezer vállalkozás kedvezô forráshoz jutását segítette eló eddig a Növekedési Hitelprogram [Perhaps Rather a Pulse Rifle... The Funding For Growth Scheme Has Provided Access to Preferential Resources For 36 Thousand Businesses]. Magyar Nemzeti Bank, www.mnb.hu/letoltes/mnbszakmai-valaszcikk-talan-inkabb-sorozatlovo-36-ezer-vallalkozas-003.pdf (accessed 18 December, 2016).

Scherer, Andreas G. - Marti, Emilio (2012): The Normative Foundation of Finance. In: Learning from the global financial crisis. Stanford University Press, Stanford, 260-290, https://doi.org/10.11126/stanford/9780804770095.003.0016.

Sóvágó, Sándor (2011): Keresleti és kínálati tényezôk a vállalati hitelezésben [Demand and Supply Factors in Corporate Lending]. MNB-tanulmányok 94, Magyar Nemzeti Bank, www.mnb.hu/letoltes/mt94.pdf (accessed 12 February, 2016).

Varga, J. (2014): Innovation as a Key Factor to Increasing National Competitiveness. In: Annual Research Conference on Advancement in Business, Science and Technology. Istanbul, 142-155.

Williamson, Oliver E. (1998): Corporate Finance and Corporate Governance. The Journal of Finance, vol. 43, no. 3, 567-591, doi: 10.1111/j.1540-6261.1988.tb04592.x. 